\title{
Challenges for managing smart cities initiatives: an empirical study
}

\author{
Wala Abdalla \\ Dr Suresh Renukappa \\ Faculty of Science and \\ Engineering \\ Engineering \\ University of Wolverhampton \\ University of Wolverhampton \\ Wolverhampton, United Kingdom Wolverhampton, United Kingdom \\ w.abdalla@wlv.ac.uk \\ suresh.renukappa@wlv.ac.uk \\ Dr Subashini Suresh \\ Faculty of Science and \\ Engineering \\ University of Wolverhampton University of Wolverhampton \\ Wolverhampton, United Kingdom Wolverhampton, United Kingdom \\ s.subashini@wlv.ac.uk \\ Razan Al-Janabi \\ Faculty of Science and \\ Engineering \\ R.Al-Janabi@wlv.ac.uk
}

\begin{abstract}
Extensive urbanisation is increasing on a global scale. The urban population is estimated to rise to 66 per cent by 2050. This significant urbanisation growth drives the consumption of resources causing resource shortages and posing significant environmental and social concerns. To manage these concerns municipal decision makers' attempt to leverage the smart city concept with collaboration between external actors as a means to maintain the prepossessed living standard in the city. The philosophy of smart cities is to see challenges as opportunities and take advantage of other trends such as digitalization. Smart cities may offer a major market opportunity that can be easily exploited by information and communication technologies providers and their telecom equipment partners. However, although the opportunity exits, capitalizing on it is not as straightforward as it seems. This paper investigates the predominant challenges in smart city initiatives from the municipal decision makers' perspective. The study is based on the findings of a survey conducted via 65 participants from various small and medium enterprises and large organisations. The results show that smart cities decision makers mainly perceive challenges with various technical and non-technical issues such as collaboration, economical, governance, social acceptance, and awareness of technology, as well as high technological risk, security and privacy of users and cyber-crimes issues.
\end{abstract}

Keywords-smart cities; challenges; technical; non-technical; collaborative communities

\section{INTRODUCTION}

More than half of the world's population is living in cities and this number is anticipated to continuously grow to $60 \%$ in 2030 [14, 46]. The Mckinsey Global Institute (MGI) has estimated that between now and 2025; the world's urban population will grow by 65 million people a year. The world population has been steadily concentrating in cities [14, 41]. The population density of cities is vital for the environment, innovation, economic development, and so much more. This significant urbanisation growth drives the consumption of resources causing resource shortages and climate change. We are facing environmental stresses and global warming problems; cities consume $75 \%$ of world's energy and produce $80 \%$ of its GHG emissions. Climate change drives cities to increasingly set targets and policies towards improving energy efficiency, increasing the share of renewable energy use, and reducing environmental impacts [2]. The rush to urban centres, particularly in emerging economics, is driven by a desire for a better life with more opportunities, as economics start to centralise in cities, so do people [14]. Providing better services whilst meeting the significant requirements for business to retain global competitive, in addition to the increasing pressure is to lessen our environmental footprint and achieving climate change targets are the major challenges for cities around the world [2]. Expenses on enhancing energy efficiency, renovating, and improving infrastructure and on generating better living quality, and working environments, are vast. Then again, cities have inadequate financial assets for governance and amenities. As a result, they necessitate an efficient management to the limited resources $[36,39]$.

Cities are under pressure to reduce resources consumption, both in terms of the amount of money they spend on delivering services and the carbon footprint across the city; for physical, social and economic resources [16]. Hence, there is a crucial need for innovative delivery systems and to generate smarter infrastructures to efficiently manage and control resource consumption in cities [2, 16]. Desmond and Kotecha [22] noted that successive governments have increasingly focused on digital transformation. Bouton, et al., [14] claimed that smart growth is the best way to do that sustainably, added that in order to deal with budget pressure, cities must find innovative ways to collect, control, and use their resources efficiently. For instance, Sao Paulo has improved value-added-tax incomes not by raising the rate but by using creative ways in tax collection [14]. Therefore, and within the current situation, the development of smart cities is so critical to cope with the growing challenges. However, there are many examples where major cities are lagging behind [48].

However, "smart cities" is a complex concept and still new, therefore it is debatably raising questions on how to manage and implement smart city initiatives. Challenges in smart city initiatives range from technical to governance to managerial challenges [35]. One of the major challenges is financing difficulties and lack of budget, lack of robust digital infrastructure, and lack of collaboration. Additionally, citizens' privacy and security are of the main issues confronting smart cities initiatives [46].

\section{SMART CITIES}

The term smart city is a fuzzy concept, not well defined in theoretical researches nor in empirical projects. Several definitions, different from each other, have been proposed. There are many definitions for the concept of 'smart city', reflecting the various perceptions of the concept, and the different disciplinary and institutional views through which a city can be viewed $[4,35]$. In view of that, Kitchin $[34,35]$ 
classify two different understandings of 'smart' cities. First, the term is often used to refer to the increasing scope to which cities are composed of pervasive and ubiquitous (ICT), in different urban structures and management systems [51]. Next, the term has similarly been used to reflect the broader benefits to the economy and to innovation that can be increased by emerging and increasing the knowledge economy in a city region. In this perception, ICT is perceived as a platform for understanding ideas and innovations, particularly relating to the professional services [23].

Kourtit, et al., [36] added that the notion of a 'smart city' is understood to refer more generally to the development of a knowledge economy within a city-region. Based on this viewpoint, a smart city is a city whose economy and governance are being determined by innovation, creativity, and entrepreneurship. Hence, and in consistence with Dixon et al., [23], ICT is perceived as being of dominant significance as the platform for assembling and understanding notions and innovations, particularly with regard to professional services [34, 49].

Nonetheless, the notion of smart city is mainly interrelated to the European Union's goals and strategies in the upcoming period and it is presented in the strategic EU document Europe 2020 [26, 32]. This particularly means reducing energy consumption and $\mathrm{CO} 2$ emissions. As a result, there will bring about better living environment and enhanced innovation opportunities related to it [32]. Hirs, et al., [32] also indicated that the smart city can be defined as a place where digital and telecommunication technologies can be deployed to enhance the efficiency of traditional networks and services for the advantage of its citizens and for businesses [27, 32].

According to The European Innovation Partnership, smart cities should be considered as systems of people interrelating with and using flows of energy, resources, and services to advance sustainable economic development, and high quality of life. These flows and collaborations become smart through developing strategic use of information and communication infrastructure and services in a procedure of transparent urban planning and management that is receptive to the social and economic needs of society [25, 32].

Smart city can be defined as a city which functions in a sustainable and intelligent way, by incorporating all its infrastructures and services into interrelated whole and using intelligent devices for monitoring and control, in order to ensure sustainability and efficiency [29]. Nonetheless, Townsend [51] debates for a more socially comprehensive notion of a smart city, where greater importance is involved to bottom up innovation, or innovation driven by citizens themselves, instead of the widely perceived 'one size fits all' top-down approach; where innovation is driven by technology companies and consultants [23].

In conclusion, smart city, and the associated innovation and technologies can deliver knowledge, products, and facilities that achieve the dual requirements of lessening greenhouse gas emissions and providing better and efficient services. The swift growth, and globalization, of ICT has the capabilities to enhance the arrangement of these solutions and their incorporation at system level since they are the main channels for cities moving into more resource efficient whilst achieving their users' needs [2, 38]. However, a numerous challenges surround the development and the implementation of smart cities projects and initiatives.

\section{SMART CITIES CHALLENGES}

Smart cities may offer a major market opportunity that can be easily exploited by ITCs providers and their telecom equipment partners. However, although the opportunity exits, capitalizing on it is not as straightforward as it seems. Several obstacles limit the potential of innovative smart technologies, like high technological risk, security and privacy of users, financial and business difficulties, uncertain returns on investment or regulatory difficulties, as well as lack of collaboration [19]. Nonetheless, the attention to risks, challenges as well as analysis of challenges that cities with smart city initiatives are faced with are less evident in the smart city literature [46]. The current literature reveals the need for more empirical research on the experience of existing smart city initiatives, especially of the challenges faced in existing initiatives.

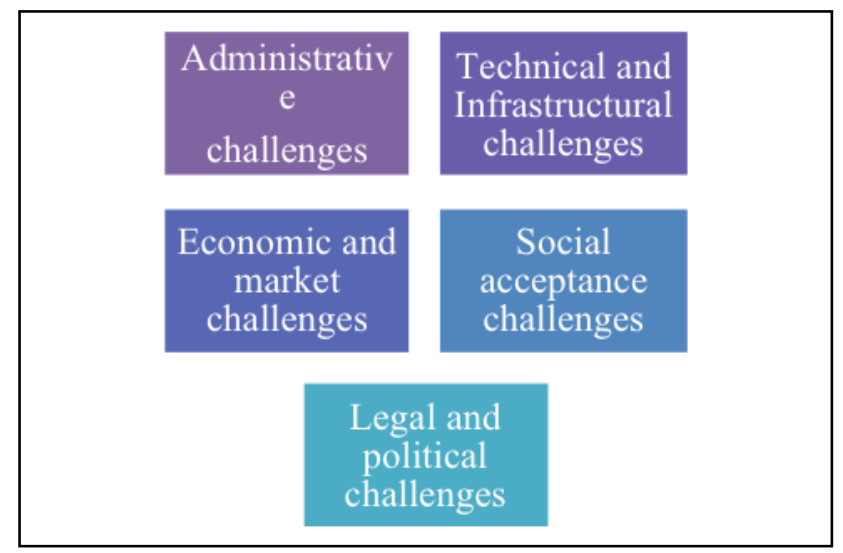

Figure 1: Smart cities challenges from literature review findings

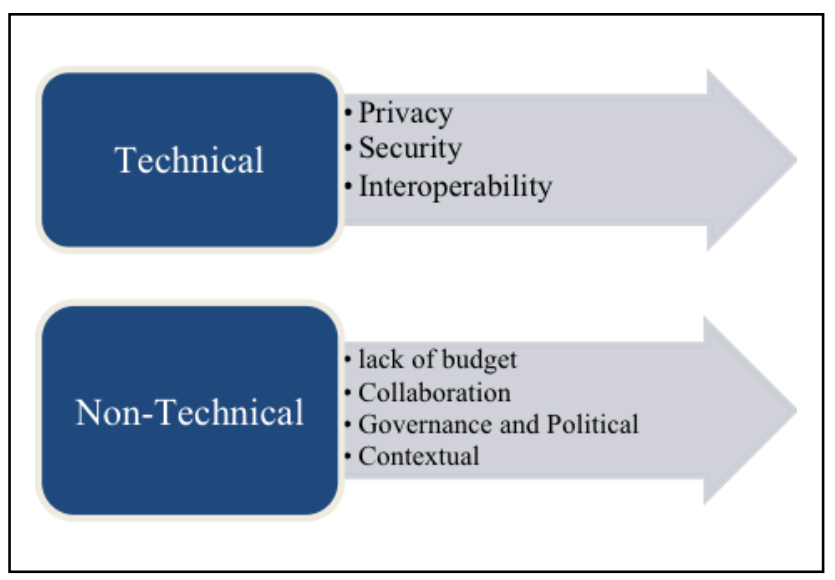

Figure 2. Technical and Non-technical challenges to smart cities initiatives 
According to the current literature findings, smart cities challenges can be categorised into administrative challenges, technical and infrastructural challenges, economic and market challenges, social acceptance challenges, as well as legal and political challenges [2] (see Fig. 1: summary of the findings). Moreover, other studies noted that the challenges that are faced by smart cities can be bifurcated into two sections: technical challenges and non-technical (business or operational) challenges (see Fig.2 and Table 1 for a summary).

\section{A. The technical challenges}

Technology use and implementation, as well as the consequences of this use for individuals and society are of the key challenges face smart cities initiatives. The most frequent occurring challenges concern: privacy, security and interoperability. From a technology perspective, smart city embeds ICT within city infrastructure. In many cases this includes diffusion of sensors and wireless sensor networks (WSN) in the city with the capability of real-time data gathering $[7,46] .$. This fusion of ICT and (internet of things) IoT [57], with urban systems requires a high degree of interoperability. Interoperability refers to the ability of different systems to interact and share information. Heo et al., [30] noted that interoperability issues that have to be solved in order for the smart city to become a reality. They concluded that tight and effective integration among city systems is a key challenge. This relates to the issue of accounting for future integration of additional systems that have to fit into the overall system architecture. Additionally, integration and collaboration are essential across different systems and components at different levels, hence, international standards are observed as vital in enhancing projects implementation. However, there is a lack in common standards for smart cities initiatives [16]. Furthermore, Zanella, et al., [57] argue that noninteroperability is a major challenge because cities have many legacy systems and heterogeneous technologies that need to be welded together in order for the smart city to develop. It is evident that overcoming interoperability issues is crucial to the smart city development [46].

Smart city also brings about several apprehensions concerning security and privacy. Bianchini and Avila [11] suggest an ethical dimension and discuss that information monitored by sensors can affect the rights of the inhabitants due to violations of the original purpose of the data collection. For example, aggregation of data could return unforeseen patterns that intrude upon the individual integrity of citizens. This view is supported by Kitchin [35] who points to ensuing risks of panoptic surveillance and argues that there is an inherent tension between development of systems to improve city governance and the threatening of citizens' right to privacy [35].

Some authors highlight data security concerns related to IoT-based smart city solutions. Tuballa and Abundo [52] draw attention to physical security, cyber security and vulnerabilities in smart grids. Additionally, Heo et al., [30] accentuate the dangers of failures in system functionality that could cause severe security threats, affecting privacy. Others identify WSN security as a key issue for smart cities [56]. In contrast, Baron [10] argues that smart city is an integrated view of the city and its infrastructures. In this understanding social and governance issues become equal to technology and infrastructure which brings about issues such as: "[...] readiness to share and use data in a privacy context; setting up standards concerning city and citizens data gathering and aggregation across huge number of microscale installations; offering data security in a large system composed of numerous sub-systems" [10].

Monzon [42] studied the conceptualisation of smart cities by considering the numerous challenges that are faced by them. One of the major challenges which are listed in majority of the researches is that people and organisations are not fully aware and informed regarding the procedures and processes of smart cities. This means that people are unaware of the concept of sustainability that hinders in the application and implementation of the smart city agenda. With the advancement in science and technology there is no aspect of life that has not been influenced. People and organisation fails to understand this influence at a basic level. This unawareness and lack of knowledge and education is a major challenge for smart cities. Lack of knowledge and skills related to smart cities, as well as limited knowledge transfer among smart city projects is also a major challenge to smart cities initiatives [36, 42].

Paroutis, et al., [45] pointed out that lack of familiarity with the technology is a major challenge that hinders the overall smart city strategy or agenda. For the purpose of delivery of a smart city agenda, it is extremely important that the stakeholders are well aware of the technology. From the perspective of both public sector and private sector technological unawareness is a major challenge for smart cities. Alawadhi [5] has stated that the current digitalisation can be considered as a challenge for smart cities development because the stakeholders have to transform the sophisticated building infrastructure into a digitized environment.

\section{B. The non-technical (buisness) challenges}

Ahvenniemi, et al., [1] noted that investment and capital are extremely important for smart cities. In this regard one of the major issues that hamper the development of local collaboration and innovation platforms is financial aspects of smart city. Lack of budget, limited funding and improper allocations of the resources and funds [15], lack of business case, the lack of clear business models [56] as well as large up-front investment costs are key challenges. According to Carvalho [18], limited public funding and private investments required for smart cities initiatives raises important questions and Manville et al., [39] point to risks of turning fixed capital to local experimental infrastructure projects and the difficulties of monetizing on smart city investments because the benefits of the "smart" capabilities takes a long time to develop. Moreover, a large part of the future infrastructure and building stock already exists, but it is outdated and needs renovation and modernisation [2]. For advanced economies, the main concern is to renovate aging infrastructure; however, for emerging ones, it is to form the 
structures necessary to support growth. Hence, the lack of resilient and robust digital infrastructure remains a major challenge for smart cities initiatives [2, 25].

Ferrer et al., [28] sum up the financial challenges of smart city by pointing to the high investment risks in innovations due to the large investment volumes required, as well as the long time for investments to reach profitability or return of expected values. Even though the cost of implementation of smart cities is extremely high but it offers immense advantages in different domains [54]. In summary, it is clear that the literature is consistently arguing that funding is of great importance for the smart city development. Moreover, smart cities initiatives should be supported by market uptake measures including the development of new business models and labelling of products and services and public procurement. Although there has been some progress in cities adopting public procurement measures to enhance smart cities initiatives, yet, examples of this being completely embedded within city procurement practices are few. Therefore, there is a lack in leading procurement models $[10,25]$.

Furthermore, collaboration is the one of the most frequent debated challenges. Collaboration concerns issues with internal silos between municipal departments, the lack of a structure to discuss relevant smart city projects with other departments as well as absence of an aligned vision for the city development [53]. Another issue is that many of the smart city initiatives are uncoordinated efforts performed independently by different city departments. The need of achieving local engagement and collaboration across departments as well as a clear definition of roles and responsibilities [8] in conjunction with weak collaborative engagement with various stakeholders [35] are considered predominant challenges.

In addition to collaboration and financial challenges the literature also discusses issues related to governance and politics. Examples of issues from a governance perspective are: challenges of providing incentives and flexible regulatory frameworks [18] and issues of institutional resistance [37]. The importance of policy-making that supports smart city development is also evident. Lee, Hancock, and $\mathrm{Hu}$ [37] express the need for decision-makers to formulate the right governance structure that will support smart initiatives. Smart cities necessitate reskilling of a significant part of the work force, including leaders and managers as the lack of leadership is one of the key challenges for smart cities initiatives [2].

The literature also emphasizes contextual challenges which refer to issues of often localized and isolated character from existing smart city initiatives due to low integration of these projects [40]. According to Hernández-Muñoz et al. [31] exportation of best practices may not occur easily because of the influence of geographical variables and locally contextualized experience of existing smart city initiatives as also identified by [39]. Manville et al. [39] further debate that local communities are likely to resist learning from other cities due to the tendency of relying foremost on local embedded experience. This probably constitutes an obstacle to the continued development of smart city.

In addition to the most frequent occurring challenges in the literature a number of authors have considered issues such as interoperability of city services and challenges of citizen engagement [10] and policies promoting stakeholder collaboration [40, 54] as well as value proposition and potential of smart cities $[7,43]$.

The findings of the literature review identified two major areas surfaced that were labelled as non-technical challenges and technical challenges. In the non-technical subset, the following aspects belong: budget and financial difficulties; business case, procurement models, collaboration, governance; and smart city roadmap, contextual; leadership, standards, and infrastructure. In the technical subset following aspects belong: privacy, security and interoperability [47] (Table 1 provides a summary of the challenges from literature review findings).

TABLE I. SMART CITIES CHALLENGES FROM LITERATRE REVIEW

\begin{tabular}{|c|c|}
\hline \multicolumn{2}{|c|}{ Smart cities challenges } \\
\hline Technical challenges & Non-technical challenges \\
\hline $\begin{array}{l}\text { Privacy: } \\
\text { - Issues related to the privacy of } \\
\text { the information monitored by } \\
\text { sensors. } \\
\text { - The implications that this } \\
\text { violation can have on citizens' } \\
\text { routines and habits in case of } \\
\text { malicious or unintentional data } \\
\text { exposure. } \\
\text { - Smart city technologies may } \\
\text { encourage increased } \\
\text { surveillance. }\end{array}$ & $\begin{array}{l}\text { Lack of budget/ financing difficulties: } \\
\text { - limited funds for smart city } \\
\text { initiatives } \\
\text { - Difficult to monetize on smart city } \\
\text { investments } \\
\text { - Large up-front investment } \\
\text { - long term delay before reaching } \\
\text { profitability. } \\
\text { - Lack of procrument models } \\
\text { - Lack of business case }\end{array}$ \\
\hline $\begin{array}{l}\text { Security: } \\
\text { - Lack of security of Big Data in } \\
\text { public clouds } \\
\text { - Lack of smart city } \\
\text { infrastructure integration } \\
\text { - Outsourcing of power and } \\
\text { control to private sector } \\
\text { providers. }\end{array}$ & $\begin{array}{l}\text { Collaboration: } \\
\text { - Weak collaborative engagement } \\
\text { with external and internal } \\
\text { stakeholders. } \\
\text { - Lack of an aligned vision of the city } \\
\text { development with stakeholders. } \\
\text { - Issues concerning institutional } \\
\text { resistance. }\end{array}$ \\
\hline $\begin{array}{l}\text { Interoperability: } \\
\text { - Issues of service } \\
\text { interoperability. }\end{array}$ & $\begin{array}{l}\text { Political, governance and politics: } \\
\text { - Challenges of defining a relevant } \\
\text { smart city roadmap. } \\
\text { - Challenges to formulating the right } \\
\text { governance structure } \\
\text { - Challenges to control creep, } \\
\text { - Political uncertainties hampering } \\
\text { public and private investments }\end{array}$ \\
\hline & $\begin{array}{l}\text { Contextual: } \\
\text { - Lack of leadership } \\
\text { - Lack of resilient and robust digital } \\
\text { infrastrcucture } \\
\text { - Influence of geographical variables. } \\
\text { - Lack of common standards. }\end{array}$ \\
\hline
\end{tabular}

\section{RESEARCH METHODOLOGY}

Hussey and Collis [33] define methodology as the overall approach to the research process, from the theoretical underpinnings to the collection and analysis of the data, so research methodology in social enquiry refers to far more than simply the methods adopted. It should encompass the 
rationale and philosophical assumptions that underlie a particular study. These, in turn, influence the methods that are used to investigate a problem and to collect, analyse, and interpret data.

Given the relatively new and unexplored nature of the research problem at hand, a quantitative method was adopted to collect and analyse data. The philosophical underpinning of this is based on objectivist-positivist paradigms [3].

Questionnaire survey instruments have many advantages in the data collection process. They provide a larger geographical coverage for the sample population than case studies or semi structured interviews could provide [13] and are cost-effective, efficient, and permit anonymity. The latter helps ensure that individuals' responses reflect their true beliefs and feelings - especially important in research involving attitudes. Because the researcher is not conversing directly with participants, they are unlikely to influence respondent answers. The questionnaire survey also provides a uniform situation for data collection, because each person is presented with the exactly the same method of inquiry, in the same manner [17].

A web-based, online survey was used to collect data. This offers many advantages including low cost, speed, and ability to reach respondents globally [48]. A robust questionnaire survey design is fundamental to obtaining reliable survey results and an appropriate response rate [17]. Hence, these aspects are further explained in the following sections.

\section{A. Questionnaire Design}

Questionnaire variables used in the study were derived from the literature review. The specific questions were written with focus on the response process, the utility of individual questions, and the overall structure and appeal of the questionnaire. The cover page introduced the research project and provided critical information such as a confidentiality statement and important notes for completing the questionnaire [3].

According to Naoum [44], three typical question types are used in questionnaire surveys: open ended and closed ended for types of question format, and scaled items for opinion questions which require subjective measurement. The study included scaled items for opinion questions. The final page of the questionnaire provided an option for respondents to offer any further general comments relating to the area of research. Respondents were also able to request a summary of the survey findings to encourage a higher response rate.

\section{B. Sample Design}

The sampling technique used was convenience sampling. According to Black [12], in convenience sampling, elements for the sample are selected for the convenience of the researcher, hence the researcher typically chooses target respondents who are readily available, nearby, or perceived as willing to participate [3].

\section{Questionnaire Response}

Survey invitations were e-mailed to respondents requesting that they submit their views via an online survey. After preliminary analysis of the data, the number of usable responses amounted to 65 from small and medium enterprises (SMEs) and large organisations.

\section{Data Analysis}

The quantitative data has been analysed with the help of statistical techniques such as descriptive analysis and the ttest. The aforementioned tests are suitable for the research because the researcher has compared the responses for SMEs and large organisations. Statistical analyses were undertaken using the Statistical Package for Social Sciences (SPSS). The researcher has applied descriptive statistics in order to present the results in an efficient and readable manner.

\section{FINDINGS, RESULTS AND DATA ANALYSIS}

Snow et al. [50] noted that building a smart city presents its designers, managers, and citizens with many technical and social problems to be solved. As mentioned above, Airaksinen et al. [2] highlighted that there exist various challenges that can impede or restrain the realisation of the development of the smart cities roadmap, including administrative, technical and infrastructural, economic and market challenges, social acceptance, as well as legal and political challenges (see Figure 1). Through the critical review of the current literature, ten key challenges for the development of smart cities were identified (Table 2).

Through the online survey, respondents were asked to indicate the extent to which they find these challenges to their organisations, on a 4-point Likert scale: "not challenging" (1), "fairly challenging" (2), "challenging" (3), "very challenging" (4).

The overall result for respondents belonging from SMEs and large organisations is shown in Table 2. The Three major challenges are: lack of budget (3.56), lack of resilient of robust digital infrastructure (3.38), and security and privacy of users and cyber-crimes issues (3.34).

Airaksinen et al. [2] noted that lack of budget and the limited and often reducing financial resources for providing governance and various services is one of the most challenging challenges to implementing smart cities projects. Airaksinen et al. [2] also highlighted that it is often hard to understand the real benefits and costs of investments and evaluate their life cycle impacts in the long term. Airaksinen et al., [2] noted that other common barriers for many smart city developments are related to systems sub-optimisation and unclear vision. BSI [16] stated that during major new infrastructure development, it is more cost-effective to install new infrastructure or the appropriate software at build stage than having to retrofit later. The challenge is that few cities have clear ideas as to their precise future smart city requirements at the present time and there are few models of what should be specified in order to cost effectively meet potential future requirements [16]. Another common barrier is that the relationship between data monitoring and services and the privacy and security of users' data is not clearly 
regulated. As data is shared between services, concerns will emerge over information security, data protection, and privacy. For Smart Cities to function effectively vast quantities of data need to be captured, stored, transferred, and destroyed on a timely basis [2]. Deloitte [20] claims that the use of disruptive technologies brings various concerns as cities become more vulnerable for cyber-crime, because much more data is stored digitally, and a plethora of physical objects are linked to the Internet. Privacy violation, hacking of connected objects, and future crimes are the most challenging concern associated with the use of disruptive technologies as stated by Deloitte [20].

TABLE II. KEY CHALLENGES FOR SMART CITIES INITIATIVES FROM EMPIRICAL STUDY

\begin{tabular}{|l|c|c|c|c|c|}
\hline Key challenges & Overall & SMEs & Large & $\boldsymbol{t}_{\text {cal }}$ & $\begin{array}{c}\text { Significant } \\
\text { value }(\boldsymbol{\rho})\end{array}$ \\
\hline Lack of budget & 3.56 & 3.49 & 3.68 & -1.231 & 0.223 \\
\hline $\begin{array}{l}\text { Defining a } \\
\text { relevant smart } \\
\text { city roadmap }\end{array}$ & 3.02 & 2.89 & 3.2 & -1.598 & 0.115 \\
\hline $\begin{array}{l}\text { Lack of } \\
\text { procurement } \\
\text { models }\end{array}$ & 3.22 & 3.18 & 3.28 & -0.557 & 0.580 \\
\hline $\begin{array}{l}\text { Lack of } \\
\text { collaboration } \\
\text { between } \\
\text { stakeholders }\end{array}$ & 3.33 & 3.36 & 3.28 & 0.459 & 0.648 \\
\hline $\begin{array}{l}\text { Lack of buisness } \\
\text { case for smart } \\
\text { cities }\end{array}$ & 3.22 & 3.26 & 3.16 & 0.564 & 0.575 \\
\hline $\begin{array}{l}\text { Security and } \\
\text { privacy of users } \\
\text { and cyber-crimes } \\
\text { issues }\end{array}$ & 3.34 & 3.33 & 3.36 & -0.136 & 0.892 \\
\hline $\begin{array}{l}\text { Lack of resilient } \\
\text { and robust digital } \\
\text { infrastructure }\end{array}$ & 3.38 & 3.33 & 3.46 & -0.680 & 0.499 \\
\hline $\begin{array}{l}\text { Lack of } \\
\text { leadership }\end{array}$ & 3.31 & 3.33 & 3.28 & -0.274 & 0.785 \\
\hline $\begin{array}{l}\text { Lack of common } \\
\text { standards }\end{array}$ & 3.27 & 3.38 & 3.08 & 1.628 & 0.109 \\
\hline $\begin{array}{l}\text { Lack of } \\
\text { knowldege } \\
\text { related to smart } \\
\text { cities }\end{array}$ & 3.33 & 3.24 & 0.483 & 0.631 \\
\hline
\end{tabular}

\section{DISCUSSION}

The overall assessment of the quantitative analysis has shown that there are certain challenges that are faced by the smart cities in the domain of business and technology. The primary data of this research has pointed out that one of the major challenges in implementing smart cities projects is the limited financial resources available. Also, it is hard to understand the real benefits and costs of investments, and evaluate their life cycle impacts in the long term. The lack of investment and capital funds are a major threat to the proper implementation of smart city strategies. However, Ahvenniemi, et al., [1] argued that the cost of implementation of smart cities is extremely high but it offers immense advantages in different domains.

Smart cities is a quite new principle, hence, people and organisations are not fully aware and informed regarding the procedures and processes of smart cities. Therefore, this unclear vision and the lack of knowledge represents a major challenge for implementing smart cities initiatives. Similarly, the research that is carried out by Monzon [42] concluded that one element that majorly hinders the application of procedures of smart cities is lack of awareness among the concerned people. This lack of awareness creates challenges at a very basic level for the smart cities.

Cities need to define a robust roadmap and to develop clear smart city strategies which provide better certainty for all stakeholders. Numerous stakeholders' integration, communication and collaboration necessitate lots of efforts. Moreover, the essential collaboration across different levels, systems and components makes it vital to develop common standards to promote projects implementation.

Furthermore, using ICT for a more connected critical urban infrastructure (e.g. energy, transport) highlights many privacy and security threats as well as threats cyber-crimes issues.

\section{CONCLUSION AND RECOMMENDATIONS}

Smart cities are highly digitized cities by nature, characterised by large volumes of data stored digitally and large numbers of physical objects with an online connection to the Internet. This can be used in a positive way, by contributing to societal goals, but it is also possible to abuse the possibilities for criminal purposes. There exist various challenges that can impede the development of smart cities initiatives. They include technical and non-technical aspects. The limited and often reducing financial resources for providing governance and various services is one of the most challenging barriers in implementing smart cities projects. Additionally, it is often hard to understand the real benefits and costs of investments and evaluate their life cycle impacts in the long term.

In view of all that has been mentioned so far, data security and privacy issues seems to be viewed as equally urgent issues in the smart city transformation together with challenges of interoperability. The literature expresses many more, challenges from various stakeholders' perspectives. Some authors reported challenges related to lack of infrastructure integration and ensuring accessibility of data and services in the smart city, as well as issues related to collecting big data and finding value in the analytics. Other publications raised concerns in regard to measuring costbenefits and the returns of smart city investments. Smart city infrastructures represent another challenge. Smart cities face the risks of relying too much on technology and solution providers causing technological lock-in effects.

The paper concludes that the key challenges smart cities face are: lack of budget, securing investment, lack of a appropriate roadmap, lack of common standards and collaboration issues; lack of related knowledge, training and educational programmes, lack of robust digital infrastructure, and security and privacy of users and cyber-crimes issues. This paper has provided some initial entry points, but wider synoptic overviews and in-depth empirical studies are required to examine existing and potential smart urbanism.

The study findings both from the literature review and the empirical findings show that interoperability on the technical side as well as knowledge and awareness on the 
non-technical side are challenges that need to be overcome in order to have successful smart city initiatives. Therefore, more effective integration and knowledge sharing within and across smart cities initiatives is required. Establishing a collaborative network with both internal and external stakeholders would be pivotal and should be addressed thoroughly and in the early planning. Opportunities to reflect on lessons which could benefit future projects are missed. Therefore, it is important to develop a comprehensive framework of the most predominant challenges with smart city initiatives.

\section{REFERENCES}

[1] Ahvenniemi, H., Huovila, A., Pinto-Seppä, I. and Airaksinen, M, "What are the differences between sustainable and smart cities?" Cities, vol. 60, pp.234-245, 2017.

[2] Airaksinen, M., Porkka, J., Vainio, T., Huovila, A., Hukkalainen, M., Ahvenniemi, H., Rämä, P. and Pinto-Seppä, I., "Research roadmap report smart city vision," 2016.

[3] Akintoye, A., Renukappa, S. and Lal, H., "Developments in the United Kingdom dispute resolution process," Journal of Legal Affairs and Dispute Resolution in Engineering and Construction, vol. 7(1), p.A4514004, 2014.

[4] Albino, V., Berardi, U., and Dangelico, R., "Smart cities: definitions, dimensions, performance, and initiatives," Journal of Urban Technology, vol. 22(1), pp. 3-21, 2015.

[5] Alawadhi, S., Aldama-Nalda, A., Chourabi, H., Gil-Garcia, J.R.,Leung, S., Mellouli, S., Nam, T., Pardo, T.A., Scholl, H.J. and Walker, S, "Building understanding of smart city initiatives," In International conference on electronic government, pp. 40-53. Springer, Berlin, Heidelberg, 2012.

[6] Antwi, S.K. and Hamza, K., "Qualitative and quantitative research paradigms in business research: A philosophical reflection," European Journal of Business and Management, vol. 7(3), pp.217225, 2015.

[7] Baccarne, B., Mechant, P. and Schuurman, D, "Empowered cities? An analysis of the structure and generated value of the smart city Ghent,". In Smart City , pp. 157-182, Springer, Cham, 2014.

[8] Bakıc1, T., Almirall, E. and Wareham, J, "A smart city initiative: the case of Barcelona," Journal of the Knowledge Economy, vol. 4(2), pp.135-148, 2013.

[9] Balakrishna, C, . "Enabling technologies for smart city services and applications. In Next Generation Mobile Applications, Services and Technologies (NGMAST), 6th International Conference on, pp. 223227, IEEE, 2012.

[10] Baron, M, "Do we need smart cities for resilience," Journal of Economics \& Management, vol. 10, pp.32-46, 2012.

[11] Bianchini, D. and Avila, I, "Smart cities and their smart decisions: Ethical considerations," IEEE Technology and Society Magazine, vol. 33(1), pp.34-40, 2014.

[12] Black, K, "Business statistics: Contemporary decision making," John Wiley and Sons, Jefferson City, MO, 2010.

[13] Bourque, L. B., and Fielder, E. P, "How to conduct selfadministered and mail surveys, Sage, Thousand Oaks, CA, 1995.

[14] Bouton, S., Dearborn, J., Sergienko, Y., and Woetzel, J, "Unlocking the future: The keys to making cities great," McKinsey and Company, 2015.

[15] Breuer, J., Walravens, N. and Ballon, P, "Beyond defining the smart city. Meeting top-down and bottom-up approaches in the middle," Tema. Journal of Land Use, Mobility and Environment, 2014.

[16] British Standards Institution (BSI), "The Role of Standards in Smart Cities," 2014.

[17] Bryman, A., and Bell, E, "Business research methods," Oxford University Press, U.K, 2007.
[18] Carvalho, L, "Smart cities from scratch? A socio-technical perspective," Cambridge Journal of Regions, Economy and Society, vol. 8(1), pp.43-60, 2014.

[19] Cities Today, "Changing cities, delivering innovations. Cities Today. Connecting the world's urban leaders. The apps which are changing the way we travel," 2017.

[20] Deloitte "Smart Cities. How rapid advances in technology are reshaping our economy and society". Version 1.0, 2015.

[21] Deren, L., JianJun, C. and Yuan, Y, "Big data in smart cities," Science China-Information Sciences, vol. 58(10), 2015.

[22] Desmond, J., and Kotecha, B, "State of the UK Govtech market. Public helping start-ups transform the public sector," 2017.

[23] Dixon T., Wetering J., Sexton M., Ling Lu S., Williams D., Duman D., Chen X, "Royal Institution of Chartered Surveyors (RICS), 2017.

[24] Elmaghraby, A.S. and Losavio, M.M, "Cyber security challenges in Smart Cities: safety, security and privacy," Journal of advanced research, vol. 5(4), pp.491-497, 2014.

[25] European Commissions, "Smart Cities and Communities. The European Innovation Partnership on Smart Cities and Communities," 2013.

[26] European Union, "Europe 2020, A Strategy for Smart, Sustainable and Incl interoperability usive Growth," European Commission. 2010.

[27] European Union, "Digital agenda for Europe. The European Union Explained," 2014.

[28] Ferrer, J.N., Costa, S., Chira, C., Deambrogio, E., Horatz, M., Lindholm, P., Nielsen, D., Pasic, E. and Bhana, R, ."Using EU funding mechanisms for smart cities," SC a. communities, ed., Smart Cities stakeholder platform, 2013

[29] Hancke, G.P., de Silva, B.d.C. and Hancke Jr, G.P, "The role of advanced sensing in smart cities," Sensors (Switzerland), vol. 13(1), pp. 393-425, 2013.

[30] Heo, T., Kim, K., Kim, H., Lee, C., Ryu, J.H., Leem, Y.T., Jun, J.A., Pyo, C., Yoo, S.M. and Ko, J, "Escaping from ancient Rome! Applications and challenges for designing smart cities,"Transactions on Emerging Telecommunications Technologies, vol. 25(1), pp.109119, 2014.

[31] Hernández-Muñoz, J.M., Vercher, J.B., Muñoz, L., Galache, J.A., Presser, M., Gómez, L.A.H. and Pettersson, J, "Smart cities at the forefront of the future internet," In The future internet assembly, pp. 447-462, Springer, Berlin, Heidelberg, 2011.

[32] Hirs, J., Dermekova, S., Wawerka, R., Volarik, T. and Mohelnikova, $\mathrm{J}$, "Information modelling process based on integrated data acquisition," Energy and Buildings, vol. 130, pp. 122-130, 2016.

[33] Hussey, R., and Collis, J, "Business research: A practical guide for undergraduate and postgraduate studies," Palgrave Macmillan, London, 2003.

[34] Kitchin, R, "The real-time city? Big data and smart urbanism," GeoJournal, vol. 79(1), pp. 1-14, 2014.

[35] Kitchin, R., "Making sense of smart cities: addressing present shortcomings," Cambridge Journal of Regions, Economy and Society, vol. 8(1), pp.131-136, 2015.

[36] Kourtit, K., Nijkamp, P. and Arribas, D, "Smart cities in perspective - a comparative European study by means of self-organizing maps," Innovation: The European Journal of Social Science Research, vol. 25(2), pp. 229-246, 2012.

[37] Lee, J.H., Hancock, M.G. and Hu, M.C, "Towards an effective framework for building smart cities: Lessons from Seoul and San Francisco," Technological Forecasting and Social Change, vol. 89, pp.80-99, 2014.

[38] Lu, D., Tian, Y., Liu, V.Y. and Zhang, Y, “The performance of the smart cities in China-A comparative study by means of selforganizing maps and social networks analysis," Sustainability (Switzerland) 7(6), pp. 7604-7621, 2015. 
[39] Manville, C., Cochrane, G., Cave, J., Millard, J., Pederson, J. K., Thaarup, R. K.,...Kotterink, B, "Mapping smart cities in the EU. Directorate General for Internal Policies, Policy Department A: Economic and Scientific Policy," European Parliament's Committee on Industry, Research and Energy, 2014.

[40] Mattoni, B., Gugliermetti, F. and Bisegna, F, "A multilevel method to assess and design the renovation and integration of Smart Cities," Sustainable Cities and Society, vol. 15, pp.105-119, 2015.

[41] McKinsey and Company, ."Economic development and sustainability must go hand in hand," 2011.

[42] Monzon, A, "Smart cities concept and challenges: Bases for the assessment of smart city projects," In Smart Cities and Green ICT Systems (SMARTGREENS), International Conference, pp. 1-11, IEEE, 2015

[43] Nam, T. and Pardo, T.A, "Smart city as urban innovation: Focusing on management, policy, and context," In Proceedings of the 5th international conference on theory and practice of electronic governance, pp. 185-194, ACM, 2011.

[44] Naoum, S, "Dissertation research and writing for construction students," Butterworth-Heinemann, Oxford, U.K, 2007.

[45] Paroutis, S., Bennett, M. and Heracleous, L, "A strategic view on smart city technology: The case of IBM Smarter Cities during a recession," Technological Forecasting and Social Change, vol. 89, pp.262-272, 2014.

[46] Pierce, P. and Andersson, B, "Challenges with smart cities initiatives-A municipal decision makers' perspective," 2017.

[47] Punch, K. F, "Introduction to social research: Quantitative and qualitative approaches," Sage Publications, Los Angeles, 2005.

[48] Quinn, J, "A smart and urban future. The Daily Telegraph Business," 2017.
[49] Schaffers, H., Komninos, N., Pallot, M., Trousse, B., Nilsson, M and Oliveira, A, "Smart Cities and the Future Internet: Towards Cooperation Frameworks for Open Innovation," Springer, Berlin and Heidelberg, pp. 431-446, 2011.

[50] Snow, C.C., Håkonsson, D.D. and Obel, B., A smart city is a collaborative community: Lessons from Smart Aarhus. California Management Review, 59(1), pp.92-108, 2016

[51] Townsend, A, "Smart cities: Big data, civic hackers, and the quest for a new utopia," New York: W.W. Norton and Co, 2013.

[52] Tuballa, M.L. and Abundo, M.L, "A review of the development of Smart Grid technologies," Renewable and Sustainable Energy Reviews, vol. 59, pp.710-725, 2016.

[53] Van den Bergh, J. and Viaene, S, "Key challenges for the smart city: Turning ambition into reality. In System Sciences (HICSS)," 48th Hawaii International Conference, pp. 2385-2394, IEEE, 2015.

[54] Vilajosana, I., Llosa, J., Martinez, B., Domingo-Prieto, M., Angles, A. and Vilajosana, X, "Bootstrapping smart cities through a selfsustainable model based on big data flows," IEEE Communications magazine, vol. 51(6), pp.128-134, 2013.

[55] Villanueva, F.J., Santofimia, M.J., Villa, D., Barba, J. and Lopez, J.C, "Civitas: The smart city middleware, from sensors to big data," In Innovative mobile and internet services in ubiquitous computing (IMIS), Seventh international conference, pp. 445-450, IEEE, 2013.

[56] Wu, J., Ota, K., Dong, M. and Li, C, "A Hierarchical Security Framework for Defending Against Sophisticated Attacks on Wireless Sensor Networks in Smart Cities," IEEE Access, vol. 4(4), pp.416-424, 2016.

[57] Zanella, A., Bui, N., Castellani, A., Vangelista, L. and Zorzi, M, "Internet of things for smart cities. IEEE Internet of Things journal, vol. 1(1), pp.22-32, 2014 


\section{Authors' background}

\begin{tabular}{|c|c|c|c|}
\hline Your Name & Title* & Research Field & Personal website \\
\hline Mrs Wala Abdalla & $\begin{array}{c}\mathrm{PhD} \\
\text { researcher }\end{array}$ & $\begin{array}{l}\text { Smart cities, knowledge } \\
\text { management, project management, } \\
\text { sustainability strategies for } \\
\text { competitive advantage, sustainable } \\
\text { infrastructure and sustainable } \\
\text { investment and development. }\end{array}$ & \\
\hline Dr Suresh Renukappa & Senior Lecturer & $\begin{array}{l}\text { Sustainability strategies for } \\
\text { competitive advantage; carbon } \\
\text { reduction strategies; corporate social } \\
\text { responsibility; knowledge } \\
\text { management; and sustainable } \\
\text { infrastructure investment and } \\
\text { development. }\end{array}$ & \\
\hline Dr Subashini Suresh & Reader & $\begin{array}{l}\text { Project management, knowledge } \\
\text { management, building information } \\
\text { modelling, health and safety, } \\
\text { emerging technologies, quality } \\
\text { management, leadership in change } \\
\text { management initiatives, } \\
\text { organisational competitiveness, } \\
\text { business process improvement, risk } \\
\text { management, and Six Sigma } \\
\text { leadership. }\end{array}$ & \\
\hline Mrs Razan Al-Janabi & $\begin{array}{c}\mathrm{PhD} \\
\text { researcher }\end{array}$ & $\begin{array}{l}\text { Smart and sustainable oil and gas } \\
\text { industry, project management, } \\
\text { sustainability strategies for } \\
\text { competitive advantage, sustainable } \\
\text { infrastructure and sustainable } \\
\text { investment and development. }\end{array}$ & \\
\hline
\end{tabular}

